\begin{tabular}{|l|l|l||}
\hline \multicolumn{2}{|c|}{ PublisherInfo } \\
\hline \hline PublisherName & $:$ & BioMed Central \\
\hline \hline PublisherLocation & $:$ & London \\
\hline \hline PublisherImprintName & $:$ & BioMed Central \\
\hline \hline
\end{tabular}

\title{
Good news on rotavirus vaccine?
}

\begin{tabular}{|l|l|l||}
\hline \multicolumn{2}{|c||}{ ArticleInfo } \\
\hline \hline ArticleID & $:$ & 4978 \\
\hline \hline ArticleDOI & $:$ & 10.1186 /gb-spotlight-20040713-01 \\
\hline \hline ArticleCitationID & $:$ & spotlight-20040713-01 \\
\hline \hline ArticleSequenceNumber & $:$ & 41 \\
\hline \hline ArticleCategory & $:$ & Research news \\
\hline ArticleFirstPage & $:$ & 1 \\
\hline \hline ArticleLastPage & $:$ & 3 \\
\hline \hline & & RegistrationDate : 2004-7-13 \\
\hline ArticleHistory & $:$ & OnlineDate \\
\hline \hline ArticleCopyright & $:$ & BioMed Central Ltd2004 \\
\hline \hline ArticleGrants & $:$ & \\
\hline \hline ArticleContext & $:$ & 130595511 \\
\hline \hline
\end{tabular}


Sam Jaffe

Email: sjaffe@the-scientist.com

MEXICO CITY - A reinterpretation of data concerning the first rotavirus vaccine, RotaShield, whose manufacturer withdrew it from the market in 1998, has some of the world's rotavirus experts gathered at a conference here wondering whether the risks associated with the vaccine were far less serious than originally believed.

In July of 1999, the Centers for Disease Control issued an alert about what appeared to be a statistically significant increase in intussusception - a potentially dangerous condition in which the small intestine collapses in on itself - that occurred in the days following vaccination. A cluster of 15 cases of intussusception was identified in infants who recently had the vaccine.

According to data analyzed by Lone Simonsen, a National Institutes of Health researcher, more than $80 \%$ of all cases of intussusception events that were associated with the vaccine happened with babies who received the vaccine after 4 months of age, which was at the far end of the manufacturer's recommendations. That's because, Simonsen told us, when the vaccine first appeared, many doctors were "catching up" with older babies who didn't have a chance to get the vaccine in the months before its approval. "You can't talk about the intussusception risks of RotaShield without talking about the age of the child at first dose," Simonsen told attendees at the Sixth International Rotavirus Symposium here on Wednesday (July 7) when she presented the as-yet unpublished data.

Another important element in Simonsen's appraisal of the 4-year-old data is the fact that overall intussusception rates of children given the rotavirus vaccine were the same as the baseline expectation of otherwise healthy children in the first year of life - about 1 in 3000. That suggests that RotaShield was "shaking the apple tree," Simonsen said. "RotaShield appears to have triggered an intussusception response in infants who probably would have had it anyway," Simonsen said. "It just shook out all the bad apples earlier."

The data caused some doctors in the audience to reassess their view of RotaShield. "If a vaccine triggers intussusception in infants who are going to get it anyway, that means it's not only preventing rotavirus but it's providing much safer and more watchful conditions for the intussusception to occur," Paul Offit, the chief of infectious diseases at the Children's Hospital of Philadelphia, told us.

Rotavirus is the leading cause of infant diarrhea and kills about 600,000 infants per year mostly in the developing world, according to a Centers for Disease Control and Prevention (CDC) study. In the United States, deaths are infrequent, but cost the healthcare system about \$1 billion, according to a 1997 estimate.

The RotaShield saga began in October of 1998, when the Food and Drug Administration approved it for use on infants in the United States. Within the next 9 months, more than 600,000 infants had received at least one dose of the three-dose vaccine. However, after 15 cases of intussusception appeared, all of them within 3 days of vaccination, the vaccine was withdrawn from the market by its manufacturer, Wyeth, 6 months later.

Today, after much debate, the consensus is that the rate of RotaShield-associated intussusception is 1 in 10,000, although many epidemiologists - including Roger Glass, the team leader of the viral 
gastroenteritis team at the CDC - say that the actual number is probably even lower. That is a much lower level of risk than epidemiologists had first projected in the wake of the vaccine's withdrawal. Today, the vaccine's license is owned by BIOVIRx, a startup biotechnology company that hopes to introduce it into the developing world.

But RotaShield is probably not on its way back to US markets, according to Offit. "No matter how safe it's proven to be, I doubt any doctor will forget its history and feel comfortable using it," Offit said.

However, the new analysis does bode well for two new vaccines that are now in phase III clinical trials, according to Alan R. Shaw, executive director of virus and cell biology at Merck. RotaTeq, from Merck, is an attenuated human strain, and Rotarix, from GlaxoSmithKline, is an attenuated bovine/ human reassortment vaccine. RotaShield was based on a rhesus monkey variant, one of the most virulent forms of the virus. Both companies had to increase their trial size by a factor of six and investigate intussusception events thoroughly as part of their clinical trials.

"It's my opinion that because such a strong light was shown on intussusception, the new vaccines were carefully engineered to avoid any problems with it, and therefore there won't be any of those problems," Offit said. "Ironically, it turns out that the light was probably shining on the wrong spot."

\section{References}

1. Centers for Disease Control and Prevention: Rotavirus, [http://www.cdc.gov/ncidod/dvrd/revb/ gastro/rotavirus.htm]

2. Centers for Disease Control and Prevention: Rotavirus Vaccine Fact Sheet, [http://www.cdc.gov/nip/ publications/fs/rotavirus.htm]

3. KidsHealth: Intussusception, [http://kidshealth.org/parent/system/surgical/intussusception.html]

4. Sixth International Rotavirus Symposium, Mexico City, Mexico, July 7-9, 2004, [http:/www.internationalrotavirus.com/]

5. Paul A. Offit, [http://www.med.upenn.edu/immun/Faculty/offit.html]

This PDF file was created after publication. 